University of Nebraska - Lincoln

DigitalCommons@University of Nebraska - Lincoln

\title{
Nitrogen and Phosphorus Accumulation in Pasture Soil from Repeated Poultry Litter Application
}

\author{
Zhongqi He \\ United States Department of Agriculture-Agricultural Research Service, Zhongqi.He@ars.usda.gov \\ C. Wayne Honeycutt \\ United States Department of Agriculture-Agricultural Research Service \\ Irenus A. Tazisong \\ Alabama A\&M University \\ Zachary N. Senwo \\ Alabama A\&M University \\ Donglin Zhang \\ University of Maine
}

Follow this and additional works at: https://digitalcommons.unl.edu/usdaarsfacpub

Part of the Agricultural Science Commons

He, Zhongqi; Honeycutt, C. Wayne; Tazisong, Irenus A.; Senwo, Zachary N.; and Zhang, Donglin, "Nitrogen and Phosphorus Accumulation in Pasture Soil from Repeated Poultry Litter Application" (2009). Publications from USDA-ARS / UNL Faculty. 539.

https://digitalcommons.unl.edu/usdaarsfacpub/539

This Article is brought to you for free and open access by the U.S. Department of Agriculture: Agricultural Research Service, Lincoln, Nebraska at DigitalCommons@University of Nebraska - Lincoln. It has been accepted for inclusion in Publications from USDA-ARS / UNL Faculty by an authorized administrator of DigitalCommons@University of Nebraska - Lincoln. 


\title{
Nitrogen and Phosphorus Accumulation in Pasture Soil from Repeated Poultry Litter Application
}

\author{
Zhongqi He, ${ }^{1}$ C. Wayne Honeycutt, ${ }^{1}$ Irenus A. Tazisong, ${ }^{2}$ Zachary N. \\ Senwo, ${ }^{2}$ and Donglin Zhang $^{3}$ \\ ${ }^{1}$ United States Department of Agriculture-Agricultural Research Service, New \\ England Plant, Soil, and Water Laboratory, Orono, ME, USA \\ ${ }^{2}$ Department of Plant and Soil Sciences, Alabama A\&M University, Normal, AL, \\ USA \\ ${ }^{3}$ Department of Plant, Soil and Environmental Sciences, University of Maine, \\ Orono, ME, USA and College of Resource \& Environment, Central South \\ Forestry University, Changsha, Hunan, China
}

\begin{abstract}
Poultry litter (PL) is a traditionally inexpensive and effective fertilizer to improve soil quality and agricultural productivity. However, over application to soil has raised concern because excess nutrients in runoff could accelerate the eutrophication of fresh water. In this work, we determined the contents of total phosphorus $(\mathrm{P})$, Mehlich 3 extracted $\mathrm{P}$, total nitrogen $(\mathrm{N})$, ammonium $\left(\mathrm{NH}_{4}\right)-\mathrm{N}$, and nitrate $\left(\mathrm{NO}_{3}\right)-\mathrm{N}$, in pasture soils receiving annual poultry litter applications of $0,2.27,2.27,3.63$, and $1.36 \mathrm{Mg} / \mathrm{ha} / \mathrm{yr}$, respectively, for $0,5,10,15$, and 20 years. Samples were collected from three soil depths $(0-20,20-40$, and $40-60 \mathrm{~cm})$ of the Hartsells series (fine-loamy, siliceous, subactive, thermic, Typic Hapludults) on a 3-8\% slope in the Sand Mountain region of north Alabama. PL application increased levels of total $\mathrm{P}$, Mehlich-3 extractable $\mathrm{P}$, and total $\mathrm{N}$ significantly. However, the change in $\mathrm{NH}_{4}-\mathrm{N}$ and $\mathrm{NO}_{3}-\mathrm{N}$ contents by the $\mathrm{PL}$ application was not statistically significant. Correlation analysis indicated that the contents of total $\mathrm{P}$, Mehlich 3 extracted $\mathrm{P}$, and total $\mathrm{N}$ were more related to cumulative amounts of poultry litter applied than the years of application or annual application rates alone. This observation suggested that $\mathrm{N}$ and $\mathrm{P}$ from poultry litter accumulated in soil. Predicting the build-up based on the cumulative amounts of PL application, rather than isolated factors (i.e., application year or
\end{abstract}

Trade or manufacturers' names mentioned in the paper are for information only and do not constitute endorsement, recommendation, or exclusion by the USDA-ARS.

Address correspondence to Zhongqi He, United States Department of Agriculture-Agricultural Research Service, New England Plant, Soil, and Water Laboratory, Orono, ME 04469, USA. E-mail: Zhongqi.He@ars.usda.gov 
rate), would improve the accuracy of evaluating long-term impacts of poultry litter application on soil nutrient levels.

\section{INTRODUCTION}

Poultry litter (PL, a mixture of manure and other external materials, such as bedding material) is traditionally inexpensive and used as fertilizer to improve soil quality and agricultural productivity (Franzluebbers and Stuedemann 2003, 2005, Franzluebbers et al. 2004, Jackson et al. 1977, Kingery et al. 1993, Mitchell and Tu 2006). For example, most of the 1.5 million $\mathrm{Mg}$ of broiler litter generated in Alabama during 1999 was used for fertilizing pastures (Kpomblekou et al. 2002). But overapplication of PL to soil may lead to detrimental environmental effects, such as pollution of ground and surface waters due to leaching and runoff of nutrients and soil accumulation of heavy metals (Franzluebbers et al. 2002, He et al. 2008, Kingery et al. 1994, Tazisong et al. 2005).

Nitrogen $(\mathrm{N})$ and phosphorus $(\mathrm{P})$ are two major nutrients in PL (He et al. 2006). Whereas the two elements are required for profitable agricultural practices, $\mathrm{N}$ - and $\mathrm{P}$-driven eutrophication of water ecosystems is a serious environmental concern (Tilman et al. 2001). Thus, a best management practice for poultry litter application would maintain adequate $\mathrm{N}$ and $\mathrm{P}$ for plant growth while minimizing adverse environmental impacts of PL. Soils in the Sand Mountain region of Alabama are sloping, permeable to water and dissolved constituents, and shallow to bedrock, thus constituting a system with a high potential for escape of nutrients to ground and surface (Kingery et al. 1994). For evaluating the long-term impact of PL application, a field experiment of land applied litter to pasture soils has been maintained for two decades at the Sand Mountain region of north Alabama, USA (He et al. 2008, Tazisong et al. 2005). The objectives of this study were to evaluate the impact of PL application history $(0,5,10,15$, and 20 years) on accumulation and distribution of total $\mathrm{P}$, Mehlich 3 extracted $\mathrm{P}$, total $\mathrm{N}$, ammonium $\left(\mathrm{NH}_{4}\right)-\mathrm{N}$, and nitrate $\left(\mathrm{NO}_{3}\right)-\mathrm{N}$ through soil profiles $(0-60 \mathrm{~cm})$. The impacts on trace elements and macro cations have been reported elsewhere (He et al. 2008, Tazisong et al. 2005).

\section{MATERIALS AND METHODS}

\section{Soils}

Soils were collected from slope positions (3 to $8 \%$ slope) of the Hartselle (fine sandy loam, siliceous, thermic, Typic Hapludults) soil series in the 
Sand Mountain region of north Alabama, USA. Samples were collected randomly at three locations in each field at depth increments of 0-20, 2040 , and $40-60 \mathrm{~cm}$. Soil samples in five fields had received poultry litter continuously for the past 0 (control), 5, 10, 15, and 20 years at rates of 0 (control), 2.27, 2.27, 3.63, and $1.36 \mathrm{Mg} \mathrm{ha}^{-1} \mathrm{yr}^{-1}$, respectively. These fields were hayed and fertilized with litter only and were being managed for pasture without supplemental inorganic N, P, or potassium (K) fertilizers. The soil samples were air-dried, ground to pass a 2-mm stainless steel sieve, and stored in plastic bags at room temperature. Subsamples were also ground to pass a 100 mesh screen for total metal determinations.

\section{Chemical Analyses}

To determine total $\mathrm{P}$ content, $1.0 \mathrm{~g}$ of each soil sample (100 mesh) was placed in $100-\mathrm{mL}$ Teflon beakers to which $5 \mathrm{~mL}$ concentrated nitric acid $\left(\mathrm{HNO}_{3}\right)$ was added (Kpomblekou and Tabatabai 1994). The beakers were covered with watch glasses after which they were heated to dryness and allowed to cool, after which $6 \mathrm{~mL}$ of perchloric acid $\left(\mathrm{HClO}_{4}\right)$ was slowly added to the contents and reheated at $203^{\circ} \mathrm{C}$ until a colorless residue was obtained. Total $\mathrm{P}$ in the digest was determined with inductively coupled atomic emission spectroscopy (ICP-AES, PerkinElmer Plasma 400 Emission Spectrophotometer, Norwalk, CT). For Mehlich-3 extractable $\mathrm{P}$ content, soils $(2.5 \mathrm{~g})$ were extracted with Mehlich-III [0.2 M acetic acid $\left(\mathrm{CH}_{3} \mathrm{COOH}\right)+0.25 \mathrm{M}$ ammonium nitrate $\left(\mathrm{NH}_{4} \mathrm{NO}_{3}\right)+0.015 \mathrm{M}$ ammonium fluoride $\left(\mathrm{NH}_{4} \mathrm{~F}\right)+0.13 \mathrm{M} \mathrm{HNO}_{3}+$ $0.001 \mathrm{M}$ ethylenediaminetetraacetate (EDTA)] extractant $(25 \mathrm{~mL})$ at pH 2.5 for $5 \mathrm{~min}$ prior to ICP-AES analysis (Mehlich 1984). Total N was determined by dry combustion at $1350^{\circ} \mathrm{C}$ (Elementar Americas, Inc). Soil NO3-N and NH4-N were determined colorimetrically after extraction with $2 \mathrm{M}$ potassium chloride $(\mathrm{KCl})$ using 1:5 soil/solution ratio (Keeney and Nelson 1982).

\section{Statistical Analysis}

All data are presented as the average of triplicate samples collected from different locations of each field. The ANOVA-single factor analysis was used to evaluate the differences in soil $\mathrm{N}$ and $\mathrm{P}$ contents impacted by PL application history. The Correlation Analysis Tool of Microsoft Excel was used to analyze correlation coefficients of $\mathrm{N}$ and $\mathrm{P}$ levels impacted by the rate, year and cumulative amount of PL application. As there were no field replicates for each PL application, these statistical treatments only 
reflected the variables or inhomogeneity of these field soils, and should not be considered as the estimates of field variability of PL application managements.

\section{RESULTS AND DISCUSSION}

\section{Mehlich-3 Extractable P}

In the top soil (0-20 cm) without PL application, the level of Mehlich-3 P was $30 \mathrm{mg} \mathrm{kg}^{-1}$ of dry soil (Figure 1), below the critical value of $50 \mathrm{mg} \mathrm{kg}^{-1}$ for plant growth (Sims 2000). Thus, plant growth responded positively to PL application, shown by increased hay yield with increasing PL application (Table 1). In fact, Mehlich-3 P content increased to $107 \mathrm{mg} \mathrm{kg}^{-1}$ in soil with 5-year PL application and $326 \mathrm{mg} \mathrm{kg}^{-1}$ in soil with 15 -year PL application. PL application also

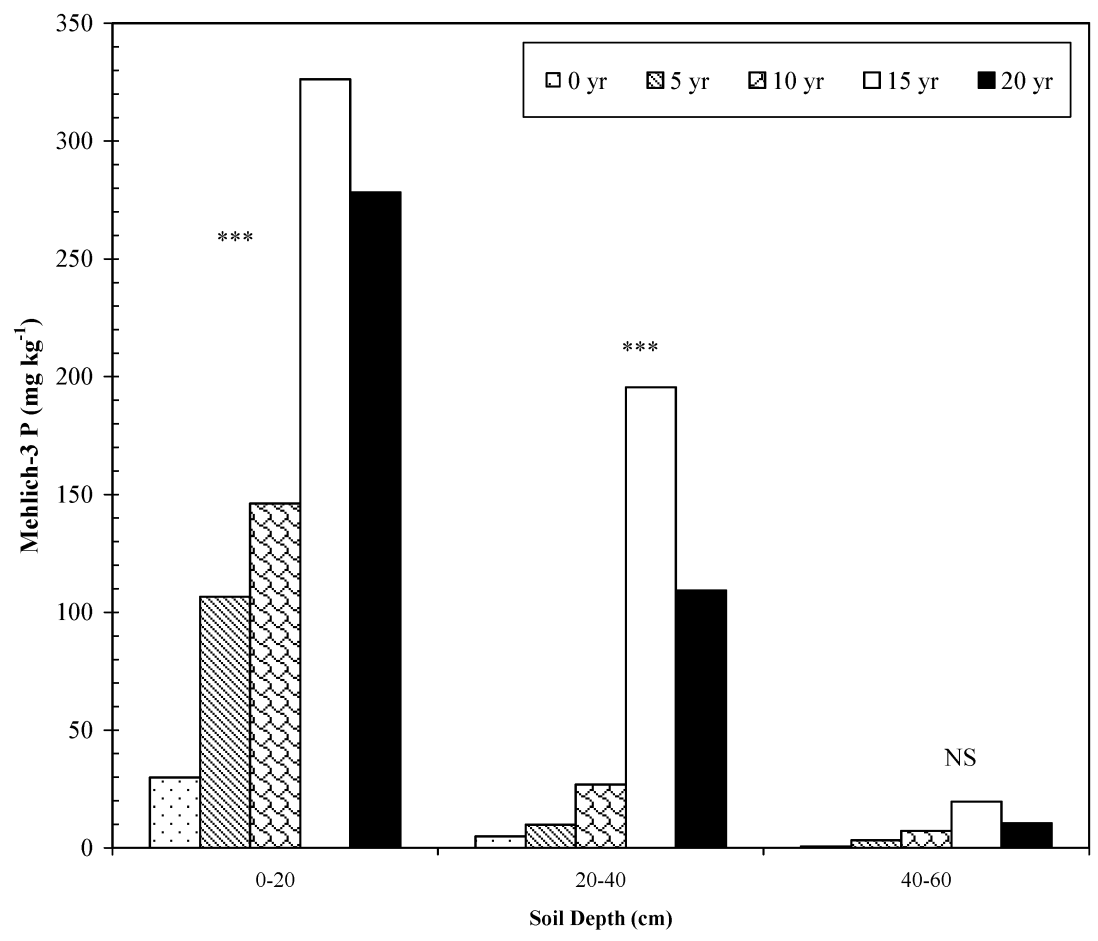

Figure 1. Changes of Mehilich-3 extracted $\mathrm{P}$ impacted by repeated poultry litter application. ${ }^{* * *}$, significance at $\alpha=0.001$; ns, no significance at $\alpha=0.05$, based on the data of triplicate sampling soils collected from each of the five fields with different PL application histories. 
Table 1. History of poultry litter application and hay yield at the five sampling fields $\dagger$

\begin{tabular}{|c|c|c|c|}
\hline \multirow[t]{2}{*}{ Year } & Annual rate & Cumulative amount & Hay yield \\
\hline & $\left(\mathrm{Mgha}^{-1} \mathrm{yr}^{-1}\right)$ & $\left(\mathrm{Mgha}^{-1}\right)$ & $\left(\mathrm{Mgha}^{-1} \mathrm{yr}^{-1}\right)$ \\
\hline 0 & 0 & 0 & 6.6 \\
\hline 5 & 2.27 & 11.4 & 7.3 \\
\hline 10 & 2.27 & 22.7 & 8.8 \\
\hline 15 & 3.63 & 54.5 & 10.4 \\
\hline 20 & 1.36 & 27.2 & 12.9 \\
\hline
\end{tabular}

$\dagger$ Data are derived from (He et al. 2008).

increased the Mehlich-3 P content in soil at 20-40 cm. The increase was greater in soils with 15- and 20-year PL application than those with 5and 10-year PL application (Figure 1).

The five fields had received PL continuously at different application rates. Thus, the cumulative amounts applied did not increase with increasing years of application (Table 1). The highest cumulative amount was $54.5 \mathrm{Mgha}^{-1}$ in the plot with $15-\mathrm{y}$ application. The increase of Mehlich-3 P was less relevant to the annual rate or the years of application, but rather more related to the cumulative amount of PL applied as shown by the correlation coefficients of 0.93 and 0.94 with the Mehlich-3 P data in the $0-20$ and $20-40 \mathrm{~cm}$ depths (Table 2). This observation indicated that not all nutrients in PL applied to soils immediately became available for plant uptake, as residual effects of manure or composition application on crop production and soil

Table 2. Correlation coefficients between PL application parameters and soil nutrient $(\mathrm{P}$ or $\mathrm{N})$ contents calculated base on the five averages of the triplicate sampling data which were significantly different at $\alpha \leqslant 0.05$

Annual applied Year of application Cumulative applied rate amount

\section{Total P}

$\begin{array}{llll}0-20 \mathrm{~cm} & 0.75 & 0.91 & 0.92 \\ 20-40 \mathrm{~cm} & 0.74 & 0.75 & 0.98 \\ 40-60 \mathrm{~cm} & 0.85 & 0.74 & 0.93\end{array}$

Mechlich-3 P

$\begin{array}{llll}0-20 \mathrm{~cm} & 0.68 & 0.92 & 0.93 \\ 20-40 \mathrm{~cm} & 0.64 & 0.76 & 0.94\end{array}$

Total N

$\begin{array}{llll}0-20 \mathrm{~cm} & 0.69 & 0.81 & 0.86 \\ 20-40 \mathrm{~cm} & 0.66 & 0.84 & 0.89\end{array}$


Table 3. Linear regression relationship between soil nutrient contents ( $\mathrm{P}$ or $\mathrm{N}$ in $\mathrm{mg} \mathrm{kg}^{-1}$ ) and the cumulative amounts $\left(\mathrm{X}\right.$ in $\mathrm{Mgha}^{-1}$ ) of PL applied calculated base on the five averages of the triplicate sampling data which were significantly different at $\alpha \leqslant 0.05$

\begin{tabular}{lll}
\hline & Linear regression & $\mathrm{R}^{2}$ \\
\hline Total $\mathrm{P}$ & $\mathrm{P}=12.6 \mathrm{X}+259$ & \\
$0-20 \mathrm{~cm}$ & $\mathrm{P}=9.9 \mathrm{X}+76$ & 0.84 \\
$20-40 \mathrm{~cm}$ & $\mathrm{P}=3.3 \mathrm{X}+109$ & 0.96 \\
$40-60 \mathrm{~cm}$ & & 0.87 \\
Mechlich-3 & $\mathrm{P}=5.6 \mathrm{X}+48$ & 0.87 \\
$0-20 \mathrm{~cm}$ & $\mathrm{P}=3.8 \mathrm{X}-18$ & 0.89 \\
$20-40 \mathrm{~cm}$ & & \\
Total N & $\mathrm{N}=18.4 \mathrm{X}+428$ & 0.74 \\
$0-20 \mathrm{~cm}$ & $\mathrm{~N}=4.4 \mathrm{X}+237$ & 0.80 \\
$20-40 \mathrm{~cm}$ & & \\
\hline
\end{tabular}

properties can last for years (Eghball et al. 2004). Linear regression analysis further revealed strong, positive correlations between the buildup of Mehlich-3 P and the cumulative amount of PL applied (Table 3). This relationship could be used as a rapid method to estimate the long-term impacts of repeated PL application on soil P (i.e., Mehlich$3 \mathrm{P}$ level), provided the correlations in Table 3 are confirmed by future studies.

Previous studies have investigated Mehlich-1 or dilute double-acidextractable P contents of Alabama and Georgia soils impacted by longterm PL application (Franzluebbers et al. 2002, Gascho and Hubbard 2006, Kingery et al. 1994, Mitchell and Tu 2006). These studies have found extractable $P$ to accumulate is mainly in the surface $20 \mathrm{~cm}$ of both pasture and cropped soils. Mitchell and Tu (2006) report that Mehlich-1 $\mathrm{P}$ in the upper $0-5$ and $5-20 \mathrm{~cm}$ is significantly related to the rate of PL application for the last year it was applied. However, some downward movement of extractable $\mathrm{P}$ has been observed mainly to a depth of $40 \mathrm{~cm}$ with a minor $\mathrm{P}$ increase at $60 \mathrm{~cm}$, demonstrating the mobility of $\mathrm{P}$ in some soils when surface concentrations are high (Gascho and Hubbard 2006). These observations are consistent with our observation reported here.

\section{Total Soil P}

In the soil without PL application, the total P content was 156, 109, and $90 \mathrm{mg} \mathrm{kg}^{-1}$ of dry soil, at the $0-20,20-40$, and $40-60 \mathrm{~cm}$ depths, respectively (Figure 2). Repeated PL application significantly increased total soil $\mathrm{P}$ in all three soil depths, although most $\mathrm{P}$ from $\mathrm{PL}$ generally 




Figure 2. Changes of total $\mathrm{P}$ impacted by repeated poultry litter application. **, and $* * *$, significance at $\alpha=0.01$, and 0.001 , respectively, based on the data of triplicate sampling soils collected from each of the five fields with different PL application histories.

accumulated in the surface $20 \mathrm{~cm}$ (Figure 2). For instance, total $\mathrm{P}$ was 847,615 , and $274 \mathrm{mg} \mathrm{kg}^{-1}$ of dry soil, at $0-20,20-40$, and $40-60 \mathrm{~cm}$, respectively, after 15-year PL application. Even so, a significant increase in total P by repeated PL application was observed at both 20-40 and 40$60 \mathrm{~cm}$ depths. This increase was greater than observed for Mehlich-3 P, indicating the $\mathrm{P}$ was less mobile and less plant available. Similar to Mehlich-3 P, total $\mathrm{P}$ was most strongly correlated with cumulative amount of PL, rather than application rates or years (Table 2). These results indicate $\mathrm{P}$ in PL was not fully harvested by the hay crop, leached or lost by runoff and most P in PL accumulated in the soil.

Few studies have investigated soil accumulation of total $\mathrm{P}$ from longterm PL application. In an earlier study, Sharpley et al. (1993) found 2-13 fold increases in total $\mathrm{P}$ in the surface $30 \mathrm{~cm}$ of 12 Oklahoma grassland soils receiving PL for 12-35 years. However, below $30 \mathrm{~cm}$, no increase in $\mathrm{P}$ content was evident. Linear regression analysis showed that total $\mathrm{P}$ increased by $12.6,9.9$, and $3.3 \mathrm{mg} \mathrm{kg}^{-1}$ in the $0-20,20-40$, and $40-60 \mathrm{~cm}$ depths for every $\mathrm{Mg} \mathrm{PL} \mathrm{ha}^{-1}$ applied (Table 3 ). In other words, for every four parts of litter $P$ that accumulated in the top soil $(0-20 \mathrm{~cm})$, another three parts of litter $\mathrm{P}$ accumulated in the $20-40 \mathrm{~cm}$ depth, and one part litter $\mathrm{P}$ accumulated at $40-60 \mathrm{~cm}$. 


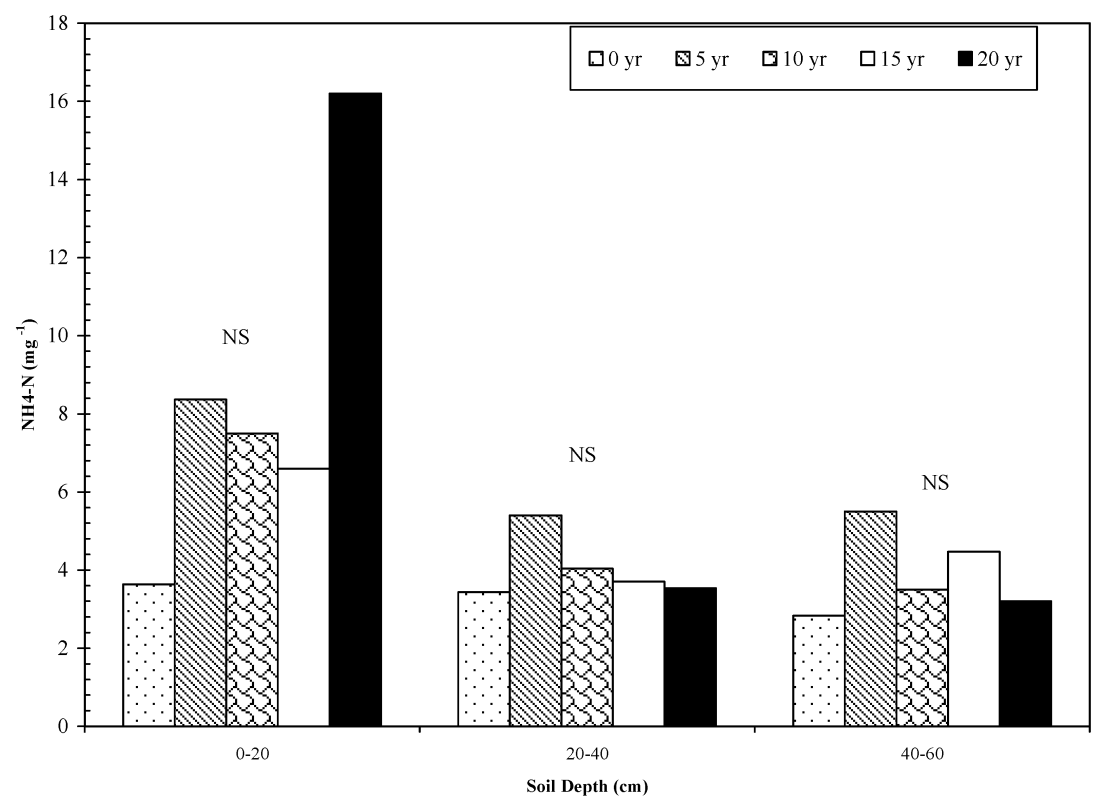

Figure 3. Changes of NO3-N impacted by repeated poultry litter application. * ns, no significance at $\alpha=0.05$, based on the data of triplicate sampling soils collected from each of the five fields with different PL application histories.

\section{Soil Inorganic N}

Soil NH4-N and NO3-N were not significantly affected by PL application (Figures 3 and 4). This statistical insignificance apparently reflects the substantial variance in $\mathrm{NO}_{3}-\mathrm{N}$ and $\mathrm{NH}_{4}-\mathrm{N}$ concentrations among the three replicate samples. For instance, the concentrations of $\mathrm{NO}_{3}-\mathrm{N}$ were $2.3,12.4$ and $3.8 \mathrm{mg} \mathrm{kg}^{-1}$ for top soil receiving 5-year PL application, and $21.3,11.4$, and $7.7 \mathrm{mg} \mathrm{kg}^{-1}$ for top soil receiving 20 -year PL application. Others have also reported inconsistent observations in inorganic N as affected by PL application (Gascho and Hubbard 2006, Kingery et al. 1994, Mitchell and Tu 2006, Sharpley et al. 1993). Sharpley et al. (1993) reported that $\mathrm{NO}_{3}-\mathrm{N}$ and $\mathrm{NH}_{4}-\mathrm{N}$ concentrations increased only in the surface $20 \mathrm{~cm}$. Kingery et al. (1994) demonstrated that even though the littered pastures had higher $\mathrm{NO}_{3}-\mathrm{N}$ concentrations than nonlittered pastures at the depths of $0-60 \mathrm{~cm}$, the differences were not considered to be of practical significance. They did however find a significant accumulation of $\mathrm{NO}_{3}-\mathrm{N}$ in soils at or near bedrock $(3 \mathrm{~m})$ where PL had been applied. Gascho and Hubbard (2006) observed that $\mathrm{NO}_{3}-\mathrm{N}$ was related to soil depth but not to PL application rate or its interaction with soil depth after 7-year PL application to a southern Coastal Plain cropland soil. Mitchell and $\mathrm{Tu}$ (2006) found that 


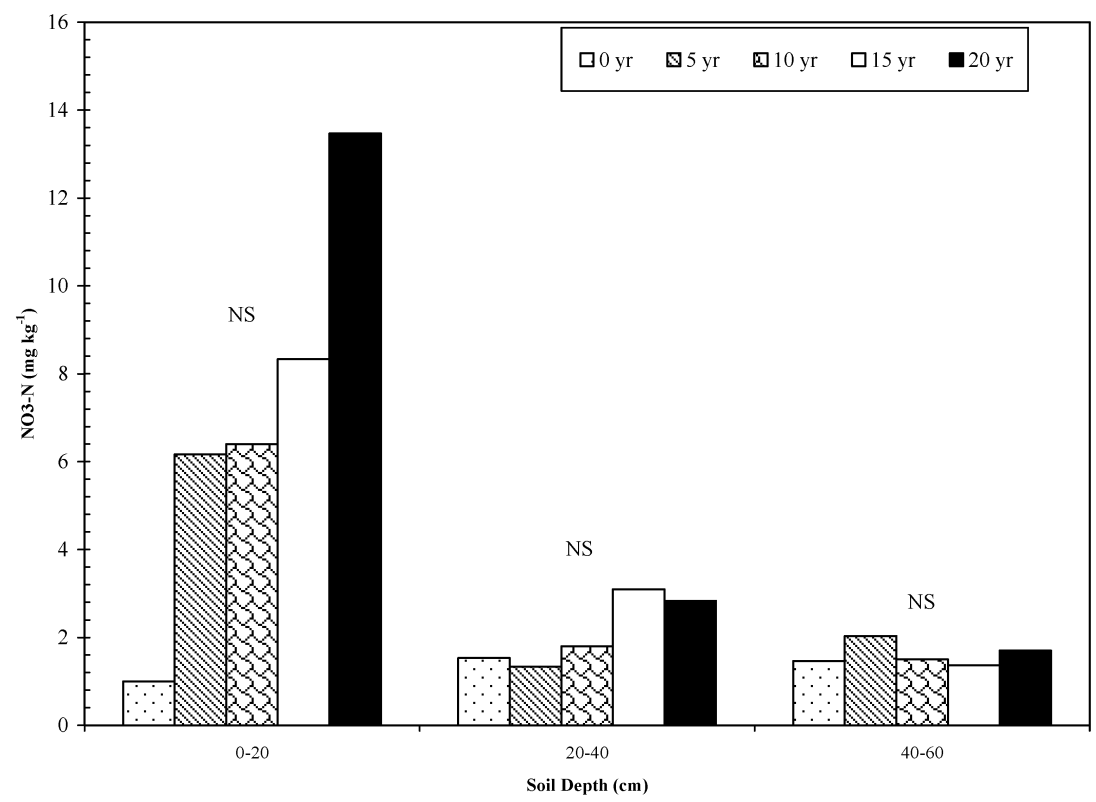

Figure 4. Changes of NH4-N impacted by repeated poultry litter application. * ns, no significance at $\alpha=0.05$, based on the data of triplicate sampling soils collected from each of the five fields with different PL application histories.

application of PL in an Alabama Coastal Plain soil over a 10-year period did not always result in significant change in $\mathrm{NH}_{4}-\mathrm{N}$, but they found a significant linear relationship between soil $\mathrm{NO}_{3}-\mathrm{N}$ and $\mathrm{N}$ rates of $\mathrm{PL}$ application.

\section{Total N Accumulation}

Long-term application of PL increased total $\mathrm{N}$ at $0-20$ and $20-40 \mathrm{~cm}$ but not at $40-60 \mathrm{~cm}$ (Figure 5). In the surface $20 \mathrm{~cm}$, total $\mathrm{N}$ ranged from $320 \mathrm{mg} \mathrm{kg}^{-1}$ in the soil without PL to $1273 \mathrm{mg} \mathrm{kg}^{-1}$ in the soil receiving $15-\mathrm{y}$ PL. In the $20-40 \mathrm{~cm}$ depth, total $\mathrm{N}$ increased from 227 to $443 \mathrm{mg} \mathrm{kg}^{-1}$ following $15-\mathrm{y}$ PL application. Like total $\mathrm{P}$, the change in total $\mathrm{N}$ was also related to the cumulative amount of PL applied (Tables 2 and 3). Soil total $\mathrm{N}$ in $0-20$ and $20-40 \mathrm{~cm}$ depths increased by 18.4 and $4.3 \mathrm{mg} \mathrm{N} \mathrm{kg}^{-1}$ soil for each $\mathrm{Mg}$ of PL ha ${ }^{-1}$ added.

The levels of soil total $\mathrm{N}$ were 40-220 times higher than those of soil $\mathrm{NO}_{3}-\mathrm{N}$ and $\mathrm{NH}_{4}-\mathrm{N}$. The lower levels of inorganic $\mathrm{P}$ were consistent with previous observations reported to reflect rapid leaching and plant uptake (Gascho and Hubbard 2006, Kingery et al. 1994, Mitchell and Tu 2006). Therefore, the high levels of total soil $\mathrm{N}$ implied most of the soil $\mathrm{N}$ was in 


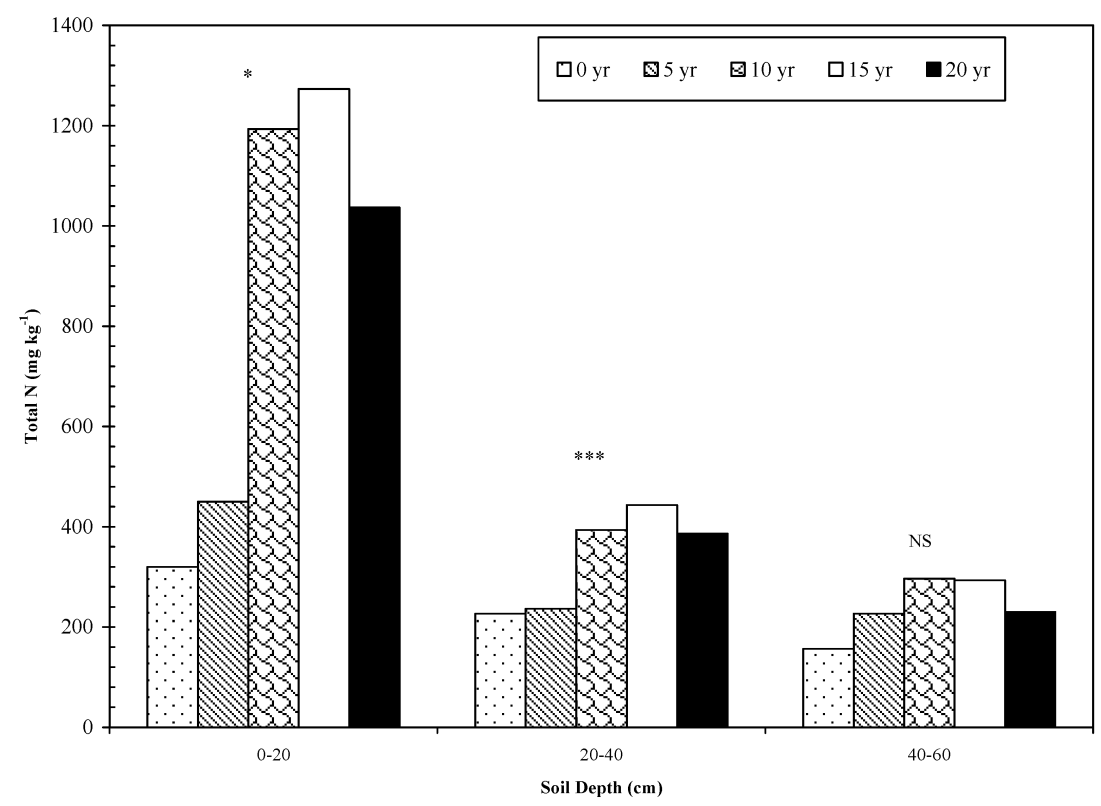

Figure 5. Changes of total $\mathrm{N}$ impacted by repeated poultry litter application. $*$, and $* * *$, significance at $\alpha=0.05$, and 0.001 , respectively; ${ }^{*} \mathrm{~ns}$, no significance at $\alpha=0.05$, based on the data of triplicate sampling soils collected from each of the five fields with different PL application histories.

the organic form. This organic $\mathrm{N}$ would become bioavailable in time through mineralization (Kingery et al., 1994). Gascho and Hubbard (2006) proposed that the accumulation of total $\mathrm{N}$ (i.e., organic $\mathrm{N}$ ) associated with PL application provided a continuous source of $\mathrm{NO}_{3}$ in the surface soil through mineralization and nitrification. These $\mathrm{N}$ transformation processes have been successfully predicted for a range of organic N sources, as demonstrated by Honeycutt et al. (1991; 2005).

\section{CONCLUSIONS}

Long-term PL application affected the status of soil $\mathrm{P}$ and $\mathrm{N}$. We examined the effects of applied litter at multiple rates and years, thus revealing their dynamic impacts. Total and Mehlich-3 extractable P concentrations increased with increasing cumulative PL applied, but the extent of these impacts decreased with soil depth. Our data indicate that the build-up of total $\mathrm{N}$ in soils was significant with long-term PL application, but not for soil $\mathrm{NO}_{3}$ or $\mathrm{NH}_{4}$. Predicting the build-up based on the cumulative amounts of PL application, rather than isolated factors 
(i.e., application year or rate), would improve the accuracy of evaluating long-term impacts of poultry litter application on soil nutrient levels.

\section{REFERENCES}

Eghball, B., Ginting, D. and Gilley, J. E. 2004. Residual effects of manure and compost application on corn production and soil properties. Agron. J. 96: 442447.

Franzluebbers, A. J., Stuedemann, J. A. and Wilkinson, S. R. 2002. Bermudagrass management in the southern piedmont USA. II. Soil phosphorus. Soil Sci. Soc. Am. J. 66: 291-298.

Franzluebbers, A. J. and Stuedemann, J. A. 2003. Bermudagrass management in the southern piedmont USA. III. Particulate and biologically active soil carbon. Soil Sci. Soc. Am. J. 67: 132-138.

Franzluebbers, A. J., Wilkinson, S. R. and Stuedemann, J. A. 2004. Bermudagrass management in the southern piedmont USA: VIII. Soil pH and nutrient cations. Agron. J. 96: 1390-1399.

Franzluebbers, A. J. and Stuedemann, J. A. 2005. Bermudagrass management in the southern piedmont USA: VII. Soil-profile organic carbon and total nitrogen. Soil Sci. Soc. Am. J. 69: 1455-1462.

Gascho, G. J. and Hubbard, R. K. 2006. Long-term impact of broiler litter on chemical properties of a Coastal Plain soil. J. Soil Water Conserv. 61: 65-74.

He, Z., Senwo, Z. N., Mankolo, R. N. and Honeycutt, C. W. 2006. Phosphorus fractions in poultry litter characterized by sequential fractionation coupled with phosphatase hydrolysis. J. Food Agri. Environ. 4: 304-312.

He, Z., Tazisong, I. A., Senwo, Z. N. and Zhang, D. 2008. Soil properties and macro cations status impacted by long-term applied poultry litter. Commun. Soil Sci. Plant Anal. In press.

Honeycutt, C. W., Potaro, L. J. and Halteman, W. A. 1991. Predicting nitrate formation from soil, fertilizer, crop residue, and sludge with thermal units. $J$. Environ. Qual. 20: 850-856.

Honeycutt, C. W., Griffin, T. S. and He, Z. 2005. Manure nitrogen availability: dairy manure in Northeast and Central U.S. soils. Biol. Agric. Hortic. 23: 199214.

Jackson, W. A., Wilkinson, S. R. and Leonard, R. A. 1977. Land disposal of broiler litter: Changes in concentration of chloride, nitrate nitrogen, total nitrogen, and organic matter in a Cecil sandy loam. J. Environ. Qual. 6: 58-62.

Keeney, D. R. and Nelson, D. W. 1982. Nitrogen-Inorganic forms. In Methods of soil Analysis, Part 2; ed. A. L. Page. ASA: Madison, WI, 643-698.

Kingery, W. L., Wood, C. W., Delaney, D. P., Williams, J. C., Mullins, G. L. and van Santen, E. 1993. Implication of long-term land application of poultry litter on tall fescue pastures. J. Prod. Agric. 6: 390-395.

Kingery, W. L., Wood, C. W., Delaney, D. P., Williams, J. C. and Mullins, G. L. 1994. Impact of long-term application of broiler litter on environmentally related soil properties. J. Environ. Qual. 23: 139-147.

Kpomblekou, A. K. and Tabatabai, M. A. 1994. Metal contents of phosphate rocks. Commun. Soil Sci. Plant Anal. 25: 2871-2882. 
Kpomblekou, A. K., Ankumah, R. O. and Ajwa, H. A. 2002. Trace and nontrace element contents of broiler litter. Commun. Soil Sci. Plant Anal. 33: 1799-1811.

Mehlich, A. 1984. Mehlich 3 soil test extractant: a modification of the Mehlich 2 extractant. Commun. Soil Sci. Plant Anal. 15: 1409-1416.

Mitchell, C. and Tu, S. 2006. Nutrient accumulation and movement from poultry litter. Soil Sci. Soc. Am. J. 70: 2146-2153.

Sharpley, A. N., Smith, S. J. and Bain, W. R. 1993. Nitrogen and phosphorus fate from long-term poultry litter applications to Oklahoma soils. Soil Sci. Soc. Am. J. 57: 1131-11137.

Sims, J. T. 2000. Soil fertility evaluation. In Handbook of soil science; ed. M. E. Sumner. CRC Press: Boca Raton, Fl., D113-D153.

Tazisong, I. A., Senwo, Z. N. and Taylor, R. W. 2005. Trends in trace elements in an Ultisol impacted by long-term applied broiler litter. Bull. Environ. Contam. Toxicol. 75: 975-981.

Tilman, D., Fargione, J., Wolff, B., D’Antonio, C., Dobson, A., Howarth, R., Schindler, D., Schlesinger, W. H., Simberloff, D. and Swackhamer, D. 2001. Forecasting agriculturally driven global environmental change. Science. 292: 281-284. 